\title{
Современные проблемы устранения микоплазменной контаминации клеточных линий эукариот в лабораторных условиях
}

\author{
(C) Г.А. Ивахова \\ Санкт-Петербургский государственный технологический институт (технический \\ университет) \\ Россия, 190013 г. Санкт-Петербург, Московский проспект, 26. \\ Email: biology.may20@gmail.com \\ Обзор включает в себя краткое изложение основных методов детекции и устранения \\ микоплазменной контаминации в культивируемых клеточных линиях эукариот, \\ применяемых в настоящее время. А также возникающие при этом проблемы, \\ связанные с физиологией микоплазм.
}

Ключевые слова: микоплазма, клетка, контаминация, мембрана, среда, культивирование.

Контаминация клеточных культур микоплазмами является достаточно сложной и серьезной проблемой для научных исследований in vitro, поскольку микоплазмы оказывают действие на физиологию клеток и их метаболизм, а также могут подавлять пролиферативную активность, влиять на ДНК/РНК синтез в клетке, способствовать развитию дегенеративных процессов клеточной системы. Токсическое и гемолитическое действие на мембраны клеток оказывают продукты метаболизма микоплазм, например, такие как перекись водорода и супероксидные радикалы. Согласно открытым источникам, от 15\% до 80\% клеточных линий контаминированы микоплазмами. В связи с этим, безопасность производимых лекарственных препаратов, так же как и чистота любого эксперимента проводимого в лаборатории, является важной задачей для современной биотехнологии.

Микоплазмы - прокариоты класcа Mollicutes, не имеют клеточной стенки и обладают малыми размерами. Мембрана большинства микоплазм содержит большое количество липопротеинов, предположительно заякоренных жирнокислотной частью, а полипептидная часть экспонирована снаружи мембраны. Микоплазмы являются самыми распространенными контаминантами клеточных культур, они тесно связаны с мембраной клетки хозяина, поэтому их еще называют «мембранными паразитами». Наиболее часто в клеточных культурах встречаются M. hyorhinis, M. orale, M. arginini, M. hominis, M. salivarium, M. laidlawii, M. fermentans, Acholeplasma laidlawii, M. pirum. Для всех представителей этого класса выявлена характерная генетическая гетерогенность и выраженная нестабильность генома, следствием этого белковые профили, отражающие экспрессию генов, могут быть подвержены изменениям. Антигенное многообразие свидетельствует о высокой степени фенотипической изменчивости. Посттрансляционная модификация метаболических фрерментов остается пока недостаточно исследованной. Стоит отметить, что некоторые микоплазмы способны проникать в клетки эукарион имея специальный аппарат инвазии. Например, M. penetrans при наличии фосфолипазной активности в своей мембране, способствующей локальному разрушению мембраны эукариотической клетки, обеспечивает проникновение микоплазмы внутрь клетки хозяина. 
Источниками заражения клеточных культур могут быть компоненты питательных сред, сыворотки, трипсин, жидкий азот при хранении в криобанке, а также сотрудник лаборатории. Меры по предотвращению микоплазменной контаминации можно разделить на три категории: поддержание в чистоте оборудования используемого для культивирования, соблюдение техники безопасности при работе с культурами клеток и соблюдение протоколов асептики в лаборатории со стороны оператора.

На присутствие микоплазменной контаминации в клеточной культуре может указывать наличие зернистости, вакуолизации, образование многоядерных клеток, изменение митотической активности, гибель клеток, раннее отторжение от стекла с образованием дефектов монослоя, а также помутнение среды вследствие ее закисления. Однако не всегда при микоплазменном заражении возможно визуальное выявление. Особенности углеводородного обмена микоплазм разделяют их условно на два типа. Микоплазмы одного типа продуцируют кислоты из углеводородов, понижая соответственно $\mathrm{pH}$ ростовой среды. Способны к сбраживанию глюкозы и лучше всего культивируются в средах с $\mathrm{pH} 8-8,5$. Наличие аргининдигидролазного пути указывает на возможность гидролиза, обеспечивающего образование ортинина, АТФ, $\mathrm{CO}_{2}$, а также аммония, и соответственно увеличение $\mathrm{pH}$ культуральной среды до щелочных значений. Присутствие аргининдигидролазного пути у другого типа микоплазм указывает на то, что при наличии в среде и глюкозы, и аргинина, образующиеся при гликолизе кислоты могут маскировать ощелачивание, вызванное высвобождением аммония при деградации аргинина. Таким образом, при проверке среды на наличие микоплазм с помощью определения $\mathrm{pH}$ и её оптической плотности, подобные явления могут искажать результат.

В настоящее время, детекция микоплазменной контаминации изложена в XIV издании Государственной Фармакопеи (ОФС.1.7.2.0031.15 «Испытание на присутствие микоплазм»), Европейской Фармакопеи (раздел 2.6.7.) и Фармакопеи США (раздел 63). Требование к чувствительности метода детекции установлено в пределах 10-100 КОЕ/мл. Методы обнаружения микоплазм принято делить на прямые и косвенные. Прямые методы: выращивание колоний микоплазм на определенной питательной среде (рекомендуемые среды - Хейфрлика, Фрея, Фрисая), окрашивание исследуемой клеточной культуры на ДНК микоплазм. Косвенные: иммунофлуоресценция, иммуноферментный анализ, ПЦР, и другие.

«Золотым стандартом» обнаружения микоплазмы в культуре является микробиологический (культуральный) метод, состоящий в культивировании исследуемого образца на селективных жидких и агаровых питательных средах при условиях наиболее благоприятных для роста и развития соответствующих видов микоплазм. В РФ в настоящее время рекомендовано испытание на присутствие микоплазм используя питательную среду, чувствительность которой определяют с помощью тест-штамма M. arginini G230, как наиболее часто встречающегося контаминанта клеточных культур. Среду используют полужидкую Каган.

Цитохимический метод для контроля присутствия микоплазм в культуре позволяет выявить трудно культивируемые виды данных бактерий. Он состоит из нескольких этапов, включающих получения монослоя клеточной культуры, чувствительной к микоплазмам, фриксирование, затем окрашивание специфическим фрлюоресцирующим красителем ДНК и визуализацию при помощи люминесцентного микроскопа.

Метод полимеразной цепной реакции (ПЦР) представляет собой многократное увеличение части генома используя определенные праймеры с последующей детекцией различными способами (например с помощью электрофореза). ПЦР тест основан на детекции $16 \mathrm{~S}$ рPНК для наиболее распространённых видов микоплазм. В случае использование ПЦР метода, заявленный предел обнаружения считается 1-10 копий генов микоплазмы на 1 мкл образца, но недостаточно определенным будет соотношение 
числа копий ДНК в пробе и КОЕ микоплазмы в 1 мл первоначального образца. Кроме этого, сложно учесть влияние состава пробы - составляющих питательной среды и самих клеток, как живых, так и мертвых. Несмотря на то, что ПЦР тест является высокоспецифичным и чувствительным, на него требуется затраты по времени, и может не оказаться в результате различия между живыми клетками и мертвыми или среды загрязнения.

Окрашивание Hoechst может быть выполнено быстро и позволяет напрямую визуализировать клетки, зараженные микоплазмой. Однако оно отобразит всю клеточную ДНК, без разделения на ДНК микоплазмы и клетки-хозяина. Стоит отметить метод ELISA быстрый и относительно простой способ, используется для определения антител микоплазмы в культивируемых клетках, но его недостаток заключается в способности обнаружить только ограниченный перечень видов микоплазм. В случае использования моноклональных антител, выявление микоплазм ограничено интенсивным темпом изменения поверхностных антигенов. Одним из новых подходов по обнаружению микоплазм является использование аптамеров - молекул одноцепочечной ДНК или РНК размером ориентировочно 20-60 нуклеотидов. С помощью процедуры Cell-SELEX можно отбирать аптамеры на специфические белковые маркеры, расположенные на поверхности мембран микоплазм. Также как и белковые антитела, аптамеры могут фрормировать строго определенную пространственную конформацию и узнавать свои цели с высокой степенью аффинности и специфичности, а также распознавать различные структурные состояния одного и того же белка. Одним из основных недостатков этого метода является быстрая деградация аптамеров нуклеазами, которые могут содержаться в питательных средах, а также возможное проявление кросс-реактивности аптамера при связывании с некоторыми другими структурно родственными молекулами. При использовании аптамеров в качестве метода обнаружения микоплазм, данная процедура может занять в целом примерно 30 минут, используя проточный цитометр, флуоресцентный микроскоп или считыватель микропланшетов.

Если клеточная линия является редкой или ценной, рекомендуется попытаться устранить заражение, в ином случае, лучше полностью утилизировать контаминированные клетки. Фактически, устранение микоплазм с помощью антибиотиков практически невозможно, учитывая, что некоторые виды могут проникать внутрь клетки-хозяина. В настоящее время существуют различные походы к попытке удаления микоплазмы из клеточной культуры: фризические (автоклавирование), химические (обработка детергентом), иммунологические (антисыворотки, специфичные для микоплазм), химиотерапевтические (использование антибиотиков). Однако ни один из этих методов не является на $100 \%$ эфрфективным и подходящим ко всем видам микоплазм, но наиболее надежным из вышеперечисленных способов является использование антибиотиков.

Ввиду биологических особенностей микоплазм, неэффективными считаются препараты ряда сульфонамидов, триметоприма, рифампина, полимиксинов, линезолида и др. Напротив, тетрациклины, фрторхинолоны и макролиды проявляют активность против микоплазм. Действие тетрациклинов основано на обратимом связывании с $30 \mathrm{~S}$ субъединицей рибосомы и предотвращением синтеза белка. У макролидов связывание происходит c 50S субъединицей рибосомы, что приводит к блокированию синтеза пептидной цепи. Фторхинолоны действуют на связывание ДНК-гиразы и/или ДНКтопоизомеразы IV, в результате чего происходит подавление репликации ДНК. Использование только одного антибиотика скорее всего приведет к появлению устойчивости к нему. Считается, что эфрфективность использования антибиотиков против микоплазм составляет $66-85 \%$.

Анализ литературы по проблеме микоплазменной контаминации клеточных культур позволяет сделать вывод о том, что применяемые методики наиболее эффрективны при их комбинировании, учитывая особенности строения и функционирования мико- 
плазм. Можно предположить, что решить проблему устранения микоплазменной контаминации можно будет изучив молекулярно-генетические механизмы адаптации микоплазм к стрессовым условиям, определяющих их выживание.

\section{Литература}

1. Борхсениус С. Н., Чернова О. А., Чернов В. М., Вонский М. С. Микоплазмы: молекулярная и клеточная биология, взаимодействие с иммунной системой млекопитающих, патогенность, диагностика // Спб. Изд. Наука. 2002. С. 2-136.

2. Laleh Nikfarjam, Parvaneh Farzaneh Prevention and Detection of Mycoplasma Contamination in Cell Culture // Cell Journal (Yakhteh). Vol 13. No 4. 2012. P. 203-212.

3. Шалунова Н. В., Волкова Р. А., Волгин А. Р., Петручук Е. М., Бердникова 3. Е., Эльберт Е. В., Шевцов В. А., Рукавишников А. В., Семенова И. С., Меркулова О. В., Трусов Г. А., Терешкина Н. В., Рачинская О. А., Индикова И. Н., Лебединская Е. В., Мыца Е. Д. Микоплазмы - контаминанты клеточных культур // БИОпрепараты. Профрилактика, диагностика, лечение. 2016. Т. 16. № 3. С. 151-160.

4. Катола В. М. Микоплазмы: биология, распространение и роль в патологии // Бюллетень Инст. Геол. и Природ. Вып. 69. 2018. С. 50-54. DOI: 10.12737/article_5b975abf813ab8.91657125

5. Суханова С. М., Бердникова 3. Е., Тихонова А. С. Совершенствование методики оценки качества питательной среды для выявления микоплазм // БИОпрепараты. Профрилактика, диагностика, лечение. 2019. Т. 19. № 3. С. 161-168.

6. Quanyuan Wan, Xiaohui Liu, Zihua Zeng, Zhenghu Chen, Yanting Liu and Youli Zu Aptamer Cocktail to Detect Multiple Species of Mycoplasma in Cell Culture // Int. J. Mol. Sci. 2020. 21. P. 3784; doi:10.3390/ijms21113784

7. Лахин А. В., Тарантул В. 3., Генинг Л. В. Аптамеры: проблемы, пути их решения и перспективы // ACTA NATURAE | T. 5. № 4 (19). 2013. C. 37-48.

8. Yanting Liu, Wenqi Jiang, Shuanghui Yang, Jianzhong Hu, Wei Han, Jianguo Wen, Zihua Zeng, Jianjun Qi, Ling Xu, Haijun Zhou, Hongguang Sun, Youli Zu Rapid Detection of Mycoplasma-Infected Cells by an ssDNA Aptamer Probe // ACS Sens. 2019. 4. P. 2028-2038. DOI: 10.1021/acssensors.9b00582.

9. Чернова О. А., Медведева Е. С., Музыкантов А. А., Баранова Н. Б., Чернов В. М. Микоплазмы и их устойчивость к антибиотикам: проблемы и перспективы контроля микоплазменных инфекций и контаминаций клеточных культур // ACTA NATURAE | T. 8. № 2 (29). 2016. С. 27-38.

10. Глинских Н. П., Бахарев А. А., Устьянцев П. В., Устьянцев И. В. Использование криобанков клеточных культур в вирусологии и биотехнологии // Ветеринарная патология. 2007. № 4. С. 209-211. 
Current problems with elimination of mycoplasma contamination of eukaryotic cell lines in laboratory conditions

G. A. Ivakhova

Saint-Petersburg State Institute of Technology

Russia, 190013 Saint-Petersburg, Moskovsky prospect, 26.

Email: biology.may20@gmail.com

The overview includes short summery of basic methods for mycoplasma contamination detection and elimination in culturing eukaryotic cell lines currently applied, and also arised problems associated with mycoplasmas physiology.

Keywords: mycoplasma, cell, contamination, membrane, medium, culturing. 